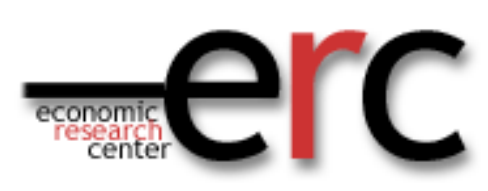

ERC Working Papers in Economics 12/03

April 2012

\title{
Gender Effects of Education on Economic Development in Turkey
}

\author{
Aysit Tansel \\ Department of Economics \\ Middle East Technical University \\ Ankara 06800 Turkey \\ Email: atansel@metu.edu.tr \\ Tel: 0090(312)210 2057 Fax:0090(312)210 7964 \\ Institute for the Study of Labor (IZA) Bonn, Germany \\ and \\ Economic Research Forum (ERF) Cairo, Egypt \\ Nil Demet Gungor \\ Department of Economics \\ Atilim University, Ankara, Turkey \\ Email: ndgungor@atilim.edu.tr \\ Tel: 0090(312)5868605
}




\title{
GENDER EFFECTS OF EDUCATION ON ECONOMIC DEVELOPMENT IN TURKEY ${ }^{1}$
}

\author{
Aysit Tansel \\ Department of Economics, Middle East Technical University, Ankara, Turkey, \\ Institute for the Study of Labor (IZA) Bonn, Germany and \\ Economic Research Forum (ERF) Cairo, Egypt. \\ E-Mail: atansel@metu.edu.tr \\ Telephone: 903122102057 \\ Fax: 903122107964 \\ and \\ Nil Demet Güngör \\ Department of Economics, Atilim University, Ankara, Turkey \\ E-Mail: ndgungor@atilim.edu.tr \\ Telephone: 903125868605
}

April 26, 2012

Keywords: Labor Productivity, Economic Development, Education, Gender, Turkey

JEL Codes: O11, O15, I21, J16

\footnotetext{
${ }^{1}$ This research is funded by Gender Economic Research and Policy Analysis (GERPA). We would like to thank Prof. Dr. Yılmaz Özkan for his encouragement.
} 


\begin{abstract}
Several recent empirical studies have examined the gender effects of education on economic growth or on steady-state level of output using the much exploited, familiar cross-country data in order to determine their quantitative importance and the direction of correlation. This paper undertakes a similar study of the gender effects of education using province level data for Turkey. The main findings indicate that female education positively and significantly affects the steady-state level of labor productivity, while the effect of male education is in general either positive or insignificant. Separate examination of the effect of educational gender gap was negative on output. The results are found to be robust to a number of sensitivity analyses, such as elimination of outlier observations, controls for simultaneity and measurement errors, controls for omitted variables by including regional dummy variables, steady-state versus growth equations and considering different samples.
\end{abstract}




\section{Introduction}

This study is concerned with the separate output effects of female and male education, as well as output effects of educational gender gap. In the recent growth literature, it is well accepted that female and male education affects the output levels and growth in different ways. First of all, female as well as male education expands productivity directly and indirectly as higher output increases physical capital investments. In addition to these separate productivity effects of female and male education there are a number of different channels through which female education plays a role in economic development and growth. Female education reduces fertility and infant mortality, improves household and child nutrition and health, increases life expectancy and increases the quantity and quality of children's education. These effects of increasing female education can increase output levels and growth indirectly. The rates of return to education estimates based on micro individual earnings data underestimates the true contribution of female education to output, since the indirect effects are ignored in the micro data. Macro data captures the direct as well as the indirect effects of female education, although even the macro data cannot encapsulate the positive effects of female education in home production on measured productivity. Further, the indirect effects of female education are important especially in developing countries. Therefore, this study concentrates on the total effect of female education and separately of male education on output in Turkey. As evident in the literature, there is controversy surrounding the gender effects of education on growth. This paper attempts to provide new evidence on this issue from the perspective of a single country rather than a cross-country viewpoint.

This paper aims to estimate the separate long-run effects of female and male education and pertains to the provinces of Turkey for the period 1975-2000. The model developed by Knowles, Lorgelly and Owen (2002) is taken as the basis of the estimating equations. This framework of Mankiw, Romer and Weil (1992) is based on Solow (1956) and Swan (1956). Knowles Lorgelly and Owen augmented the Mankiw, Romer and Weil model to include separate female and male education capital and health capital variables. Knowles et al. (2002) criticize the previous literature on growth as ad hoc and provide a theoretical framework where it is possible to relate the long-run effects to output elasticities of physical capital, female and male schooling, and health capital. 
In addition to estimating the separate long-run effects of female and male education this study also employs a reparametrization of the model $\grave{a}$ la Knowles et al. (2002) to examine the effect of the educational gender gap on output. The methodology we use includes robust regression on pooled panel data controlling for regional and time effects. The results are found to be robust to a number of sensitivity analyses, such as elimination of outlier observations, controls for simultaneity and measurement errors, controls for omitted variables by including regional dummy variables, steady-state versus growth equations and considering different samples.

For given levels of male and female education, the gender gap in education might negatively affect output and growth through several channels. According to Dollar and Gatti (1999), the educational gender gap leads to a misallocation of resources while Klassen (2002) believes it restricts the access to employment and technology. Empirical literature using crosscountry data does not have a consensus on the effect of female education on productivity. Barro and Lee (1994) and their subsequent contributions (see next section for references) find a negative effect of female education and a positive effect of male education on growth while Hill and King (1993; 1995) and Knowles et al. (2002) find a positive effect of female education on output using cross-country data. This study, which employs cross-provincial data for Turkey, finds that female education positively affects output while the effect of male education is either positive or insignificant. Further, the educational gender gap is found to reduce output. These findings point to the importance of female education in development and growth, in addition to that of male education and an adverse effect of the educational gender gap on output for both the developed and less developed provinces of Turkey.

Section 2 reviews the literature on the gender separate effects of educational capital on output and growth, as well as the effects of the educational gender gap. The empirical growth model with separate female and male education and health capital à la Knowles et al. (2002) is outlined in Section 3. Section 4 provides background information on Turkey and the data used in this study together with recent developments in educational attainment levels in Turkey. Estimation results using various techniques are presented in Section 5. Concluding remarks and policy implications appear in Section 6. 


\section{Previous Studies on the Effect of Male and Female Education on Economic Growth}

\section{Separate Effects of Male and Female Education}

Recent literature on empirical growth in the late 1980s and early 1990s included human capital as a main determinant of growth. These writings started with Lucas (1988) and Romer (1990). Subsequent studies, such as Barro (1991), Mankiw Romer and Weil (1992) and Islam (1995) provided empirical evidence on the impact of education on growth. Various cross-country or time series studies produced uncontested evidence that increasing educational levels and health improves labor productivity contributing to greater economic growth. More recently researchers investigated the effect of male and female education separately on economic growth. The empirical evidence on the separate effects of male and female education on economic growth have been contradictory and not as theoretically expected in several studies. In this section we provide a brief summary of the studies on the separate effects of male and female education on growth.

Benavot (1989) was the first researcher to point out that male and female education may impact economic development differently since the dynamic effect of the increase in female education differs from that of male education in particular on labor force participation, age at marriage, fertility and migration. Barro and Lee (1994) extended the earlier work of Barro (1991) to include not only education but also health in their definition of human capital. They further, investigated the separate effects of male and female education as measured by average years of school attainment. They estimated growth equations with the seemingly unrelated regression equation (SURE) method using cross-country data for 95 non-oil producing countries for two time periods 1965-1975 and 1975-1985. Their controversial finding is that while male education is positively related to growth, the female education is negatively related to growth. They explained this "puzzling" (Barro and Lee, 1994: 18) result by suggesting on the same page that the large gender gap in education is "a good measure of backwardness; hence, less female attainment signifies more backwardness and accordingly higher growth potential through the convergence mechanism." Stokey (1994) replicating Barro and Lee (1994)'s results finds that the coefficient on female education becomes insignificant when regional dummy variables are included in the estimation. She also notes the multicollinearity between male and female education variables. Lorgelly and Owen (1999) also replicated the Barro and Lee estimates and subjected them to a number of tests for 
identifying influential observations and outliers. Like Stokey, they too find that the influential observations on the East Asian countries of Hong Kong, Singapore, Korea and Taiwan are responsible for the "puzzling" finding in Barro and Lee study. Further exclusion of other influential observations led to statistical insignificance of the both male and female education variables. They conclude that Barro and Lee's results are sensitive to the samples used and Barro and Lee's "backwardness" explanation is unconvincing.

Barro and Sala-i-Martin (1995), and Barro (1996a; 1996b) extend the Barro and Lee (1994) model by including educational details such as male and female secondary and higher education. The results in these studies are consistent with those in Barro and Lee (1994) in that male secondary and higher education coefficients are statistically significantly positive while those on female education coefficients are negative. Further work with similar specifications such as Barro (1997, 1999a and 1999b) used an extended data set with the main finding that female education coefficients are no longer statistically significant. Perotti (1996) is another author who finds similar results to Barro and his associates in the sense that the growth effect of male education is positive and significant while that of female education is negative and significant. Durham (1999), while investigating the effect of political regimes on growth, finds that the effects of male and female education on growth are both insignificant. However, when he considers the less developed sample, the effect of male education is negative and that of female education is positive, and both are statistically significant.

Schultz (1995) estimated two simple regressions of output for 1970 and 1980 on expected years of male and female school enrollments for 65 countries. He found significant and positive effects of male and female education on output where the coefficient for female education was larger than that of the male.

Caselli, Esquivel and Lefort (1996) pointed out the econometric estimation problems in the Barro and Lee studies. They argued that the estimates of male and female education coefficients in the growth equations suffer from inconsistency. This inconsistency could be a result of the omitted variable bias due to misspecification of the country-specific effects. It could also result from ignoring the possibility of simultaneous causation between growth and education variables. In order to solve inconsistency they used GMM estimation which eliminate the country-specific effects and instrumental variable estimation with lagged values of the independent variables as instruments to address the simultaneity issue. They used panel 
feature of the cross-country data on 97 countries with observations on five year periods for the 1960-1985 period. They estimated an extension of the Mankiw, Romer and Weil (1992) as well as an extension of the Barro-Lee generic estimation equation. They obtained results opposite to those of Barro and Lee. Their statistically significant education variables were positive for female education and negative for male education indicating a complete reversal of the signs from that of the Barro and Lee results. They accept that "both results are puzzling because, ... there is no theory that is consistent with different signs for male and female human capital” (p. 379). Forbes (2000) uses the first-difference GMM estimator and Yamarik and Ghosh (2004) employ a system GMM estimator to deal with the problems of omitted variable and endogeneity bias. They too find a positive and statistically significant effect of female education on growth. The effect of male education on growth was either insignificant (Forbes) or negative and statistically significant.

A further examination of the separate effects of male and female education on growth is carried out by Dollar and Gatti (1999). Contrary to previous studies they measured male and female education by the percentage of the male and female population who completed secondary school. The equation they estimated is the basic panel growth model. In one version they added male and female secondary school proportions separately. In another version they used educational gender inequality as measured by the differential between female and male educational attainment. They found a negative coefficient estimate on male education and a positive one on female education both of which were only marginally significant. They also addressed the potential endogeneity of both the male and female education and carried out the instrumental variables estimation with results similar to the initial estimates. They further divided the sample into groups of developed and developing countries by using the female educational attainment as the criterion. Those countries where the percentage of the female population with some secondary school attainment is larger than 10.35 were considered as developed. Their estimation results for the developing countries yielded insignificant coefficient estimates on the male and female secondary school attainments. However, their results for the developed countries resulted in an insignificant (negative) coefficient on male secondary school attainment and a significant positive coefficient on the female secondary school attainment. These findings for the developed countries are similar to Caselli et al. findings but opposite of the Barro and Lee findings for the full set of countries. 
Klaitzidakis et al. (2001) address the issue of nonlinear educational effects with panel data. They find that the female education and growth are positively related at low levels of schooling and negatively related at high levels of schooling, while male education and growth are positively related at high levels of schooling. Boopen (2006), in a time series analysis for Mauritius, finds that both female and male education, as measured by the secondary enrollment ratio, affect economic growth positively and significantly.

\section{Evidence with Gender Gap in Education}

Another group of researchers focused on the effect of the gender gap in education on productivity and economic growth. The main contention here was that the educational gender gap hinders economic growth. This is also viewed as a way of reducing the possible high multicollinearity between the male and female education variables. Hill and King (1993 and 1995) were the pioneering studies utilizing this approach. Hill and King estimated an output production function with inputs of the stock of physical capital, the labor force, the female secondary enrollment rate and the educational gender gap as measured by the female to male enrollment ratio. Here they used either the female to male enrollment ratio at the primary level or at the secondary level whichever is the smallest. They used data for five-year periods between 1960-1985 for a sample of 152 countries. Their OLS estimation with the pooled data yielded significant positive coefficients on capital stock, labor force and female secondary enrollment rate and significant negative coefficient on educational gender gap variable. Their simulation results indicate that among the two otherwise similar countries in terms of their level of female education, labor force and capital stock, a country with the larger educational gender gap will have $25 \%$ lower output than a country with smaller educational gender gap. At the micro level, Kara (2006) finds that promoting the education of women reduces gender inequalities by decreasing the gap in wage differentials in higher education.

Sadeghi (1995) estimated a simple GDP growth equation on gender gap in literacy levels and further on gender gaps in primary or secondary enrollment rates. In all cases, he found significantly negative coefficients for all the educational gender gap variables on output growth.

Klassen (2002) followed a more extensive approach and investigated both the direct and the indirect effects of educational gender gap. He also argued against use of male and female education variables separately due to possible high multicollinearity between them. In 
his growth equation he included a variable for total level of education and a variable for the educational gender gap in order to identify their separate effect on growth. Unlike Hill and King (1993 and 1995) who sought to explain levels of GDP, he used growth of per capita GDP as his explanatory variable. His growth equation included initial values of total education and gender gap in education as well as their growth rates and other variables. The gender gap in education was measured by female to male ratio of years of schooling. The growth rates were computed over the 1960-1990 period. His main finding is that both the initial educational gender gap and the rate of growth of educational gender gap have significantly positive effects on economic growth. Addressing the issue of endogeneity of the educational variables using instrumental variables estimation produces similar findings. $\mathrm{He}$ also concludes that the causality runs from educational gender gap to economic growth and not the other way around.

Unlike previous studies which were mostly ad hoc estimates, Knowles, Lorgelly and Owen (2002) based their estimates on a theoretical model. Their model is an extension of the neoclassical growth model ala Mankiw, Romer and Weil (1992). They include male and female education and health capital separately. They further reparametrized the model to include educational gender gap. Their interest is to estimate the long-run steady-state relationship for per capita output. They estimate it by OLS using a single cross-section data on variables averaged over the period 1960-1990 for 72 developed and developing countries. The unmeasured country-specific effects are taken into account by including initial technology measure. They also use instrumental variables estimation to take into account possible endogeneity of education variables. In the original formulations the coefficient estimate on female education is significantly positive while that on male education is insignificant. In the reparametrized models, the coefficient estimate on female education is insignificant while that on educational gender gap is significantly negative. The results are similar to those obtained by Hill and King $(1993,1995)$ and Klassen (2002) but contradict the Barro and Lee findings. In an attempt to reconcile Barro and Lee results they estimate their equation with initial values using 1990 data. They find that the coefficient on male education is significantly negative while that on female education is insignificant. 


\section{Background on Educational System in Turkey}

A preliminary examination of the data informs us on the mean years of schooling of the males and females in the seven regions of Turkey given in Table 1. Significant regional gender differences on male and female mean years of schooling are observed in this Table. The region with the highest male education attainment is Marmara between 1970-1990. In 2000, the Central Anatolia region has the highest educational attainment for the male labour force. The Marmara region has the highest female educational attainment levels throughout the period 1970-2000. The region with the lowest attainment for both males and females is Southeast Anatolia throughout 1970-2000. Further details can be found in Tansel and Güngör (1997).

Table 2 gives the gender gap in education as measured by the ratio of female educational attainment to the male mean years of schooling. For all of the regions this ratio is less than one indicating that the female mean years of schooling is less than that of the male. Values of this ratio close to unity indicate gender educational equality. However, values close to zero indicate very high levels of the educational gender gap. The table indicates that there is a significant educational gender gap even in the developed regions of Turkey such as Marmara and the Aegean. As observed in this table, the smallest educational gender gap is observed in the developed regions such as Marmara and Aegean. The largest educational gender gap, on the other hand, is observed in the region of Southeast Anatolia. The table also indicates that in all regions the educational gender gap decreased over time even in the Southeast Anatolia where educational gender gaps persist strongly.

Other educational statistics for the rural urban areas in Turkey indicate larger educational gender gaps in rural as opposed to urban areas in Turkey. Some families in less developed regions especially in rural areas do not send their daughters to schools even at the compulsory levels.

Tables 1 and 2 indicate a significant jump in the male and female years of schooling and significant decline in gender gap in education in the year 2000. This is most apparent in the Southeast Anatolia region. This could be attributed to the educational reform of 1997 which increased compulsory schooling from 5 to 8 years. 
An examination of the educational composition of the labor force (not shown) indicates that in 1970 the majority of the labor force had no formal schooling, whereas in 1990, the majority of the labor force had completed at least the primary schooling of 5 years. Further, the proportion of those who completed at least the primary level of schooling increased from 78 percent in 1990 to 83 percent in 2000 .

Finally, we note in Figure 1, that the rate at which the regional gender gap is closing differs by the regions of Turkey. This figure shows that the Southeastern Anatolia has the fastest decline in educational gender gap between 1985 and 2000, although it still remains the region with greatest gender disparity.

Table 3 gives the regional disparities in male and female educational attainment levels. All regions are compared to the Marmara region, which as we noted, has the highest education attainment levels for both males and females in Turkey. The table gives the ratio of the educational attainment of each region to the educational attainment in Marmara. We see that regional disparities in educational attainment have nearly disappeared for males in the year 2000. For females, there remains a significant gap between the Southeast and Eastern Anatolia regions and the Marmara region.

Table 4 provides distribution of female and male education of the labor force over the years for the less developed and developed province groups. As it is evident in this table, the less developed provinces have significantly lower average mean years of schooling especially for females. For both the less developed and the developed groups, the increase in the mean years of schooling is substantial. For the less developed provinces the increase is 168 percent over the period of 1975-2000, although it remains below the primary level of schooling. For the developed provinces the increase is 105 percent over the same period. Therefore we observe a faster improvement in educational attainments in the less developed provinces than in the developed provinces.

\section{Theoretical Framework}

The Mankiw, Romer and Weil (1992) human capital-augmented model of economic development provides the theoretical framework for the present study. Following Knowles et 
al. (2002), we examine the effects of female and male education on growth separately by including them as distinct factors in Cobb-Douglas constant returns to scale production function. The production technology is given by:

$$
Y_{i t}=K_{i t}^{\alpha} E F_{i t}^{\beta_{f}} E M_{i t}^{\beta_{m}} X_{i t}^{\psi}\left(A_{i t} L_{i t}\right)^{1-\alpha-\beta_{f}-\beta_{m}-\psi}
$$

where $Y$ represents the level of real output, $K$ is physical capital, $E F$ is the female educational attainment variable, $E M$ is the male educational attainment variable, $X$ is the stock of health capital, $A$ is the unobserved level of technology and $L$ is the labour force. Technology is labour-augmenting so that advances in technology lead to increases in output per worker. The female and male educational attainment variables are measured respectively as the average years of schooling of the female labour force and the average years of schooling of the male labour force. The constant returns to scale assumption ${ }^{1}$ of a Cobb-Douglas technology allows us to rewrite equation (1) in terms of per effective units of labour, denoted by lower case letters, by multiplying all factors of production by $1 / A L$.

$$
y_{i t}=k_{i t}^{\alpha} e f_{i t}^{\beta_{f}} e m_{i t}^{\beta_{m}} x_{i t}^{\psi}
$$

Lower case letters indicate that quantities are in terms of per effective units of labour. Labour grows exogenously at the rate $n$, which differs across provinces, and technology grows exogenously at the constant rate $g$. These assumptions are given by the equations $L_{i t}=L_{i o} e^{n_{i} t}$ and $A_{i t}=A_{i o} e^{g t}$. The accumulation of physical capital, female education, male education and health occurs as follows.

$$
\begin{aligned}
& \dot{k}_{i t}=s_{k i} y_{i t}-\left(n_{i}+g+\delta\right) k_{i t} \\
& e \dot{f}_{i t}=s_{e f i} y_{i t}-\left(n_{i}+g+\delta\right) e f_{i t} \\
& e \dot{m}_{i t}=s_{e m i} y_{i t}-\left(n_{i}+g+\delta\right) e m_{i t}
\end{aligned}
$$

\footnotetext{
${ }^{1}$ The assumption of constant returns to scale (CRTS) is tested by estimating Equation (2) in its restricted (CRTS) and unrestricted forms. The test results indicate that the null hypothesis of CRTS is not rejected with the data using the time average of the variables for the period 1975-2000.
} 


$$
\dot{x}_{i t}=s_{x i} y_{i t}-\left(n_{i}+g+\delta\right) x_{i t}
$$

Dots over variables indicate the rate of change for those variables. The shares of output invested in physical capital, female education, male education and health capital are given by $s_{k}, s_{e f}, s_{e m}$ and $s_{x}$ respectively. $\delta$ is the rate of depreciation, assumed to be the same for both physical and human capital, although in reality they need not be the same ${ }^{2}$.

The steady-state values for physical capital, female education, male education and health capital are obtained by setting $\dot{k}_{i t}=e \dot{f}_{i t}=e \dot{m}_{i t}=\dot{x}_{i t}=0$. These steady-state values, which are denoted by *, are substituted into equation (2) and logs are taken of both sides.

$$
\ln \left(Y_{i t} / L_{i t}\right)^{*}=\ln A_{i 0}+g t-\frac{1-\eta}{\eta} \ln \left(n_{i}+g+\delta\right)+\frac{\alpha}{\eta} \ln \left(s_{k i}\right)+\frac{\beta_{f}}{\eta} \ln \left(s_{e f i}\right)+\frac{\beta_{m}}{\eta} \ln \left(s_{e m i}\right)+\frac{\psi}{\eta} \ln \left(s_{x i}\right)
$$

where $\eta \equiv 1-\alpha-\beta_{f}-\beta_{m}-\psi$. This equation may be rewritten in terms of the steady state stocks of female education, male education, and health capital. The final estimation equation where the technology term $(g t)$ is treated as a constant and subsumed in $a$ and an error term is attached is given below.

$\ln \left(Y_{i t} / L_{i t}\right)^{*}=a+\ln A_{i 0}-\frac{\alpha}{1-\alpha} \ln \left(n_{i}+g+\delta\right)+\frac{\alpha}{1-\alpha} \ln \left(s_{k i}\right)+\frac{\beta_{f}}{1-\alpha} \ln \left(e f_{i t}^{*}\right)+\frac{\beta_{m}}{1-\alpha} \ln \left(e m_{i t}^{*}\right)+\frac{\psi}{1-\alpha} \ln \left(x_{i t}^{*}\right)+\varepsilon_{i t}$

The restricted form of this equation is

\footnotetext{
${ }^{2}$ In fact, we expect these two depreciation rates to differ. An important difference between physical capital and human capital depreciation is that, in general, physical capital (equipment, machinery, tools) wears out with use while human capital (education, skills and the like) wears out with disuse. Human capital depreciation or skill erosion can occur when an individual remains out of the workforce for a period of time (because of being unemployed, being on maternity leave, being on sick leave or due to the fulfillment of military service) or if he/she is working in a job that is unrelated to his/her skills level. Assuming the two depreciation rates to be the same simplifies the model where our main focus is on gender differences in the effects of human capital on economic development. Assuming the same depreciation rate for physical and human capital is a common assumption in the growth literature.
} 
$\ln \left(Y_{i t} / L_{i t}\right)^{*}=a+\ln A_{i 0}+\frac{\alpha}{1-\alpha}\left(\ln \left(n_{i}+g+\delta\right)-\ln \left(s_{k i}\right)\right)+\frac{\beta_{f}}{1-\alpha} \ln \left(e f_{i t}^{*}\right)+\frac{\beta_{m}}{1-\alpha} \ln \left(e m_{i t}^{*}\right)+\frac{\psi}{1-\alpha} \ln \left(x_{i t}^{*}\right)+\varepsilon_{i t}$ (9)

Equations (10) and (11) below give, respectively, the unrestricted and restricted forms of the model rewritten in terms of the gender gap and the male education variable.

$$
\begin{aligned}
\ln \left(Y_{i t} / L_{i t}\right)^{*}= & a+\ln A_{i 0}-\frac{\alpha}{1-\alpha} \ln \left(n_{i}+g+\delta\right)+\frac{\alpha}{1-\alpha} \ln \left(s_{k i}\right)+\frac{\beta_{f}+\beta_{m}}{1-\alpha} \ln \left(e m_{i t}^{*}\right) \\
& -\frac{\beta_{f}}{1-\alpha}\left(\ln \left(e m_{i t}^{*}\right)-\ln \left(e f_{i t}^{*}\right)\right)+\frac{\psi}{1-\alpha} \ln \left(x_{i t}^{*}\right)+\varepsilon_{i t} \\
\ln \left(Y_{i t} / L_{i t}\right)^{*}= & a+\ln A_{i 0}+\frac{\alpha}{1-\alpha}\left(\ln \left(n_{i}+g+\delta\right)-\ln \left(s_{k i}\right)\right)+\frac{\beta_{f}+\beta_{m}}{1-\alpha} \ln \left(e m_{i t}^{*}\right) \\
& -\frac{\beta_{f}}{1-\alpha}\left(\ln \left(e m_{i t}^{*}\right)-\ln \left(e f_{i t}^{*}\right)\right)+\frac{\psi}{1-\alpha} \ln \left(x_{i t}^{*}\right)+\varepsilon_{i t}
\end{aligned}
$$

Similarly, the model can be written in terms of the gender gap and female education variables. The corresponding unrestricted and restricted equations are not provided to save space.

\section{Data Description}

The dataset used in this study consists of data collected over four time periods for the 67 provinces of Turkey. The time periods are 1975-1980, 1980-1985, 1985-1990 and 19902000. The variables used in the regressions are average values over the period concerned. An important advantage of using regional data from a single country is that there is less likely to be variation across cross-sectional units (e.g., the provinces of Turkey) as a result of differing variable definitions and/or data collection techniques. This study therefore avoids, at least to some degree, the sort of data problems (consistency, availability and measurement) that necessarily prevail in a cross-country dataset.

While using regional data from a single country reduces the cross-sectional variation in the data, changes in definitions or collection methods over time remains a problem ${ }^{3}$. One of

\footnotetext{
${ }^{3}$ For example, the calculation of the gross provincial product (GPP) series changed after 1986. The GPP series used by the State Institute of Statistics for 1987 onward is based on the revised Gross Domestic Product series that includes previously omitted sectors. It also uses a more accurate methodology for calculating the real GPP
} 
these problems is that the cross-sections have changed with the creation of new provinces and the reorganization of sub-districts within provinces. The number of provinces in Turkey has increased from 67 in 1975 to 81 in 2000 . Thus, to keep the number of provinces the same in each year we adjust the 1990 and 2000 data by adding back the values of the new provinces to the values of the original provinces from which they were formed. There were a total of 67 provinces in the census years 1975, 1980 and 1985. By the next census in 1990, the political division of provinces had changed. Six new provinces were created from the existing provinces and the number of provinces increased to 73. By the 2000 census, there was a further increase in the number of provinces: eight new provinces were created and the total number of provinces reached 81 . The 1990 and 2000 data were adjusted in order to keep the number of provinces the same as in previous years. This was done roughly by adding the figures for the new provinces back to the provinces where they originated from. For example, Aksaray was part of Niğde initially and became a new province later on. For this reason, we added the various figures for Aksaray to the figures for Niğde in order to find the numbers for the original province structure ${ }^{4}$.

The health capital variable used is the number of hospital beds per population. We also experimented with using life expectancy and the number of hospitals per population as proxies for health capital. Industrial electricity consumption is used to approximate the rate of utilization of physical capital as it is done in the literature (Lau et al., 1993). This proxy is a good approximation to the rate of utilization of capital which is the relevant concept in the production function. The industrial electricity consumption of the provinces are obtained from the publications of the Turkish Electricity Agency authorities. Mean years of formal education completed by the male and female labor force is taken as the proxy for educational human capital. The mean years of formal education is estimated as a weighted average of the portion

series, while the older real GPP series based on Özötün's work (Özötün, 1980, 1988) is computed using sectoral deflators. In order to make the new GPP series more compatible with the earlier series, we used Özötün's sectoral deflator method to calculate the real GPP values for each province for the years 1990 and 2000 instead of using the real GPP data provided by SIS for those years.

\footnotetext{
${ }^{4}$ The newly created provinces and the original provinces from which they were created are as follows: In 1990, Aksaray was created from part of Niğde; Bayburt from Gümüşhane; Karaman from Konya; Kırıkkale from Ankara; Batman from Siirt; and Şırnak from Siirt. In 2000, Bartın was created from Zonguldak; Ardahan from Kars; Iğdır from Kars; Yalova from İstanbul; Karabük from Zonguldak; Kilis from Gaziantep; Osmaniye from Adana; and Düzce from Bolu.
} 
of the labor force that has achieved a certain level of schooling where the weights are the number of years of schooling corresponding to that level. For further details, see Tansel and Güngör (1997).

\section{Estimation Results}

\section{Estimation Issues}

Cross-country studies of economic growth and development have been criticized on various grounds. Mankiw et al. (1995), for example, raises valid objections to the use of cross-country regressions to draw inferences about the relative importance of various factors in their effect on aggregate output. These are summarized succinctly under the headings of simultaneity, multicollinearity and degrees of freedom. A panel dataset consisting of observations across time as well as cross-sectional units may circumvent some of the estimation problems associated with the use of single cross-sectional units. This study evaluates the results from both single cross-sectional regressions on time averages and pooled estimation procedures.

Endogeneity can arise due to simultaneity, omitted variables or measurement error, and can have serious consequences for the LS estimators. There is reason to believe that there may be an endogeneity problem concerning the male and female education variables. While a more educated workforce is believed to increase productivity (per labour force income), being located in more developed regions (regions with higher productivity) also implies the existence of greater opportunities for participating in education and training activities.

In addition, labour productivity is enhanced not only by the total years of schooling of the workforce, but also by the quality of the education received as well as other factors that contribute to human capital accumulation, such as access to health resources (hospitals, doctors, nurses, equipment, quality services). Not accounting for these factors is, therefore, a serious omission in a model of labor productivity.

While we do not have measures for these omitted factors, we know that they must be related to the location of the workforce. In general, developed regions have more schools, more hospitals and better quality services than less developed regions. The inclusion of 
regional dummy variables may therefore capture, to some extent, the unobserved quality of institutions across regions with differing levels of development. In equations 8-11 of the theoretical framework section, Knowles et al. (2002) use a measure of technical efficiency provided and Hall and Jones (1999) as a proxy for the term $\ln A_{i 0}$, which varies across countries but not across time. We do not have a measure of provincial technical efficiency, although we believe that technical efficiency differences among the provinces of Turkey may be captured by regional dummy variables. While technological resources may be technically available to all provinces, each province may have a different capacity for making use of different technologies due to differences in educational and other complementary resources. Inclusion of regional dummy variables may thus account for the unobserved differences in technical efficiency that may persist among the provinces and may be better represented at the regional level.

Schooling attainment (average years of schooling) is used as a proxy for human capital accumulation gained formally through the education sector. One of the shortcomings in using the average years of schooling as a measure of educational differences among provinces is that it fails to account for quality differences in education. Is a year of schooling in a developed province such as Izmir comparable to a year of schooling in a less developed province such as Bitlis? It is also questionable whether different schools within the same province provide schooling of uniform quality. Rural areas have a clear disadvantage in providing quality educational services to students compared to urban centers. Hanushek and Wößmann (2007) have pointed out, within a cross-country context, the limitations of using educational attainment levels without considering quality differences when studying the impact of schooling on economic variables such as growth and development. Even when there is a catch-up among countries in terms of the quantity of education, this does not imply a catch-up in terms of quality. Hanushek and Wößmann (2007) offer this as an explanation as to why there has not been a strong or conclusive link between schooling and growth or development in cross-country studies. They have suggested the inclusion of international test scores as a possible remedy and review the studies of the effects of quality of education on economic growth and development. In general, these studies indicate that quality of education is able to explain variations in output across countries better than quantity measures of education. In fact, the inclusion of quality measures lead to insignificance of the quantity measures such as average years of schooling. In addition, the study by Jamison, Jamison and Hanushek (2006) shows that the impact of mathematical test scores on growth is mainly 
through its positive effect on the rate of technological progress. So, these studies indicate that the inclusion of quality measures of education is very likely to change the results on the impact of education in empirical studies.

\section{Pooled Estimation Results}

In this section we consider the estimation of the main relationship in this study for explaining the steady state levels of output per worker where female and male education enter separately as explanatory variables. This relationship is given by Equation (8) in Section 3 with Equation (9) as its restricted version. The restriction is that the coefficients on the capital share and modified population growth terms sum to zero. Estimates in this section are based on data pooled over the census years $(1975,1980,1985,1990$ and 2000). We present these estimates in order to enable comparisons with the works of previous researchers who reported pooled estimates, such as Islam (1995), Hill and King (1993; 1995) and Dollar and Gatti (1999). Two main advantages of pooled data are increased degrees of freedom and reduced potential multicollinearity. A number of researchers such as Stokey (1994) and Lorgelly and Owen (1999) has shown that Barro and Lee's (1994) empirical results using cross-country data are not robust to the exclusion of countries that could be influential observations or outliers. Robust regression methods such as robust regression, least absolute error or least trimmed squares are also suggested to deal with influential observations and outliers (Rousseeuw and Leroy, 1987). We adopted the robust regression technique (rreg) and reported the estimates based on this technique. This procedure first eliminates gross outliers for which Cook's Distance is larger than unity, then performs Huber iterations followed by biweight iterations suggested by Li (1985) as performed in Stata program.

Table 5 reports the estimation results and Table 6 presents the descriptive statistics for the full sample of 67 provinces as well as for the 38 less developed and the 29 developed provinces. Less developed provinces are defined as those which are given priority in public investment by the State Planning Organization. The remaining provinces constitute the developed provinces. This division of the sample is meaningful since the literature emphasizes the role of the female education especially in the development process. Such differentials between developing and developed countries were expected by Dollar and Gatti (1999) and Knowles et al. (2002). Therefore, it may be sensible to expect differences in the estimates of female and male education in the less developed and developed provinces samples. In all the estimated equations the coefficients on both the modified population 
growth and the physical capital investment share variables are highly statistically significant. The validity of the restriction is tested with an F-test. If the validity of the restriction is not rejected, we then estimate the restricted equation (9). The restricted equation estimates (not shown) are used to derive the implied labor productivity elasticities of physical capital input, female education, male education and health capital, which are also provided at the bottom of Table 5 together with, in parentheses, their asymptotic standard errors. The stars indicate the significance levels for the test of the null hypothesis that the relevant elasticity equals zero.

For the sample of all provinces, the coefficients on female education, male education and health capital are all statistically significant. This result implies that ceteris paribus, the provinces with higher levels of female and male education will have higher levels of labor productivity. The statistical significance of the female education is reduced to 10 percent when region and time dummies are included. Further, the coefficient on male education increases substantially with the inclusion of the region and time dummy variables. Since the restriction is not rejected, the implied elasticities are also provided using the restricted model estimates. The labor productivity elasticities of all of the regressors are statistically significant. For the sample of less developed provinces, the coefficients on male education and health capital as well as their relevant elasticities are statistically significant but not the coefficient on female education. As for the sample of developed provinces only the coefficient on female education and its labor productivity elasticity are statistically significant whereas the male education and health capital are statistically insignificant. The relatively low point estimates for the physical capital investment share may be due to the use of industrial electricity consumption to approximate capital investment ${ }^{5}$. Similar results for physical capital share are obtained by Lau et al. (1993) who also used electricity consumption as a proxy.

The middle part of Table 5 provides the estimates of alternative parametrizations, which include the educational gender gap, either with female or male education. Equations (11) and (12) are respectively, the unrestricted and restricted forms of the model rewritten in terms of the gender gap and the male education variable. Since they are reparametrized versions of the Equation (8), the estimates are equivalent to those discussed in the previous paragraph of Equation (8). The sign on the gender gap variable depends on the education

\footnotetext{
${ }^{5}$ Celasun (1989) reports that the share of non-agricultural non-wage income is around 35\% in 1976-77 and rises to $70 \%$ in 1988 , where non-wage income includes rents, profits, interest payments and earnings of the selfemployed persons.
} 
variable included in the model. The expected sign on the gap variable is positive when female education is included and negative when male education is included. The statistically significant coefficients on the educational gender gap when female education is used except in the developed provinces sample reflect the significance of the elasticity of male education $\left(\beta_{\mathrm{m}}\right)$. The statistically significant coefficients on the gap variable when male education is used except in the less developed provinces sample reflect the statistical significance of the elasticity of female education. These estimates reiterate the previous estimates and further show that the educational gender gap negatively affects the labor productivity. In the case of all provinces, less developed and developed provinces the restriction $\beta_{\mathrm{f}}=-\beta_{\mathrm{m}}$ is rejected. Together with the statistical significance of the gender gap, these indicate that female and male education, as well as the gender gap, affects labor productivity. Another feature of the estimates with gender gap is its implications about multicollinearity. Researchers often commented that high multicollinearity between female and male education prevent gauging their separate effects by inflating their variances. In order to avoid multicollinearity some researchers used educational gender gap along with either of the female or male education. (Hill and King, 1993; 1995; Klasen, 2002; Knowles et al., 2002). Indeed, for the sample of all provinces, the correlation coefficient between female and male education is 0.898 , compared to -0.975 between female education and the educational gender gap, and -0.777 between male education and the educational gender gap.

The regional control variables in Table 5 suggest that there are important regional differences in labor productivity. For instance, labor productivity in the Aegean is about 10 percent lower than in the reference region Marmara, while in all other regions the relative decline in labor productivity compared to Marmara ranges from 14 percent in the Mediterranean to 37 percent in the East. In the case of all provinces, the Southeast does not statistically significantly differ from Marmara, but has 26 and 29-32 percent lower productivity respectively for the less developed provinces and the developed provinces.

In the estimates in Table 5, in the case of all provinces with time dummy variables we observe that there is a decline in labor productivity in the period 1980-1985, followed by a smaller decline in 1985-1990 relative to the reference period 1975-1980. For the period 19902000 , labor productivity is not significantly different from the level of the reference period. It 
appears that it has taken 25 years for labor productivity to get back to its previous level ${ }^{6}$. The same patterns are observed for the group of less developed provinces and the developed provinces. These findings are consistent with observations in Özmucur (1992), Uygur (1993), Taymaz and Suiçmez (2005), and Saygılı et al. (2005) who report a decline and then a rebound in labor productivity for the manufacturing sector output and for total output in the same period for Turkey. Trade liberalization policies of the early 1980's together with financial liberalization in 1989 opened up the economy to foreign competition and brought with it an improvement in labor productivity (Sayg1l1 et al, 2005: 83).

\section{Sensitivity Analysis}

In this section we report the results of a number of sensitivity analyses. These included OLS and Two Stage Least Squares (2SLS) estimates of Equations (8) and (9) using time averages of the variables over the period 1975-2000 as well as their growth equation version and reparametrizations with educational gender gap variable. In these cases we have used the robust (heteroscedasticity-consistent) standard errors since Pesaran and Smith (1995: 94) argue that they are appropriate for regressions with long time averages ${ }^{7}$. In order to deal with the issue of influential or outlier observations, robust regression and Cook's Distance (CD) criterion is used to select the observations for deletion such that $C D_{i}>4 / n$ where $n$ is the sample size ${ }^{8}$. We have also obtained estimates based on other criteria ${ }^{9}$.

\footnotetext{
${ }^{6}$ It should be noted that the 1965-1976 period is one where the government employed a successful importsubstitution strategy with government control over the financial sector. This was followed by a crisis period between 1976-1981. On January 24, 1980, a stabilization program was initiated that shifted Turkey's development strategy from an import-substitution to an export-led growth strategy with a decline in the role of the state in the economy and the liberalization of financial markets. The post 1981 period is considered to be an adjustment period under this new strategy.

${ }^{7}$ Knowles et al. (2002) use multivariate extention of the asymptotic standard errors obtained by Moon and Phillips (1998) for time averaged regressions which they find to be equivalent to the robust standard errors as well as to the conventional standard errors.

${ }^{8} \mathrm{CD}_{\mathrm{i}}$ is given by $\mathrm{h}_{\mathrm{i}} \mathrm{e}_{\mathrm{i}}^{2} / \mathrm{ks}^{2}\left(1-\mathrm{h}_{\mathrm{i}}\right)^{2}$ where hi is the leverage, $\mathrm{e}_{\mathrm{i}}$ is the residual, $\mathrm{k}$ is the number of regressors including constant, $\mathrm{s}^{2}$ is the mean squared error and $\mathrm{i}$ indicates the observation (Belsley et al., 1980).

${ }^{9}$ We have also estimated models where different criteria are used for deletion of the influential observations or outliers such as large studentized residuals, high leverage, high studentized residuals and leverage together and high DFBETA values. In these estimates the results were qualitatively similar to the ones discussed. They are not discussed but are available from the authors upon request.
} 
In the OLS estimates of Equation (8), health capital, proxied by the number of hospital beds per population ${ }^{10}$, is not statistically significant and it does not affect the significance of other variables. In the estimates for all provinces only the coefficients on female education and health capital are positive and statistically significant whereas the coefficient on male schooling is insignificant when OLS, robust regression and Cook's Distance criterion are used with and without regional dummy variables. However since a test of the restriction is rejected in all models the implied elasticity estimates cannot be computed. In the estimates for the less developed provinces, health capital is mostly statistically significant but not in the developed provinces. In both cases the restriction is mostly not rejected enabling computation of the elasticities. For the less developed provinces the elasticity estimates for both the physical capital share and the male education are positive and statistically significant. In the estimates for the developed provinces the elasticities on female education are statistically significant while those on male education are insignificant. We have also estimated alternative parametrizations, which include educational gender gap, either with female or male education. Since they are re-parametrized versions of the Equation (8), the estimates are equivalent to those discussed in this paragraph of Equation (8). In some cases both the female and the male education elasticities and in some cases only female education elasticities are positive and statistically significant. Further, as expected the sign on the gap variable is positive when female education is included and negative when male education is included implying negative effect of the educational gender gap on labor productivity.

For the purpose of comparison with studies using growth models, we estimated the extended MRW (1992) model using the growth framework in Knowles et al. (2002, Equation 18) and Knowles and Owen (1995, Equation 12'). In the estimates for all provinces and the samples of less developed and developed provinces we accept the restriction. The elasticity of female education is positive and statistically significant in all three cases, while that of male education is negative in the case of all provinces and insignificant in the cases of less developed and developed provinces. The negative and significant coefficient on male

\footnotetext{
${ }^{10}$ Life expectancy at birth is frequently used to proxy for the stock of health capital. A number of researchers such as Barro and Lee (1994), Knowles and Owen (1995; 1997) and Knowles et al. (2002) used life expectancy as an indicator of health status. Following Knowles and Owen and Knowles et al. we also used a nonlinear transformation of life expectancy at birth (LE) calculated as $\ln (\mathrm{X})=-\ln (85-\mathrm{LE})$ which gives the difference of life expectancy from 85 years. This variable was not statistically significant in most of the estimated models. Therefore, in place of life expectancy, the number of hospital beds per population is used as a proxy for health capital
} 
education is similar to the finding of Caselli et al. (1996). One might also include a set of control variables again for the purpose of comparison with Barro-Lee approach cross-country studies. However, we did not pursue this due to lack of provincial data on such variables as investment and government consumption.

A potential source of inconsistency in the coefficient estimates is endogeneity of the explanatory variables in Equation (8). There may be possible simultaneity between the education and health capital variables on the one hand and output per worker on the other as it is discussed by Bils and Klenow (1998) and Pritchett and Summers (1996). Other factors that may imply endogeneity of explanatory variables include measurement errors in the female and male education and the health capital variables as well as the omission of labor productivity enhancing variables such as the quality of education and health care services and other factors that contribute to human capital accumulation. In order to address the issue of potential endogeneity of the regressors 2 SLS estimates are carried out ${ }^{11}$. The exogeneity test of the female and male education jointly by Durbin-Wu-Hausman test and of the health capital are not rejected except in one case, implying that OLS estimates are appropriate. The 2SLS estimates support the OLS estimates in that ceteris paribus, increases in female education lead to increases in labor productivity. In conclusion, various sensitivity analyses show that in some cases both the male and female education elasticities and in some cases the female education elasticity are statistically significant supporting the pooled estimation results.

\section{International Comparisons}

It is well known that there is considerable inconsistency and contradiction in the international evidence on the effect of female and male education utilizing cross-country data.

\footnotetext{
${ }^{11}$ As suggested by Bils and Klenow (1998) and Knowles et al. (2002), a number of climate variables together with distance and population variables are used as instruments for education variables. Two different sets of instruments are considered. The validity of the instruments is tested by using Hansen test (1982) version of the Sargan test of overidentifying restrictions. The overidentifying restrictions are not rejected implying valid sets of instruments. The relevance of the instrument sets is tested with the LM version of the Anderson (1951) canonical correlation test. The null hypothesis of underidentification is rejected in all of the models. The first set of instruments includes, the altitude of the provincial center and the distance of the provincial center to Istanbul. The rest of the instruments are climate variables, which are averaged over the period 1975-2000. They include the ratio of the rain in the heaviest month to the average, the log of the highest temperature in April, the difference between the highest monthly high temperature and the lowest monthly low temperature, rainfall and the population density. The second set includes, in addition to those listed above, the urban proportion of the population. These data are obtained from TÜiK sources, Turkish Highway Directorate and the Turkish Meteorological Directorate.
} 
The very first of the studies by Barro and Lee (1991; 1994; 1996a; 1996b), Barro and Sala-iMartin (1995) and Perotti (1996) find negative and statistically significant effect of female education and positive and statistically significant effect of male education which is a result referred to as a "puzzle". Subsequent studies, such as those by Stokey (1994), Barro (1997, 1998, 1999) and Lorgelly and Owen (1999), find the effect of female education to be statistically insignificant. In contrast to these studies, Caselli et al. (1996) report that the effect of female education is positive and statistically significant, while that of the male education is negative and also significant. Forbes (2000) and Yamarik and Ghosh (2004) also find a positive and statistically significant effect of female education on growth. In Forbes'(2000) study, the effect of male education on growth is negative and insignificant, while it is negative and significant in Yamarik and Ghosh. Evans (2009) finds that female education has a significant and positive effect on economic growth when the gender gap is slight but may have negative effects as the gender gap widens. Knowles et al. (2002) find a positive and statistically significant effect of female education and insignificant effect of male education on labor productivity. Further, Dollar and Gatti (1999) and Durham (1999) find statistically insignificant effects on growth of female and male education in the total sample. However, when Dollar and Gatti (1999) split the sample into developed and developing countries, the effect of female education is positive and significant for the developed country sample while male education is not, which is similar to our findings for the developed provinces of Turkey. Further, in the pooled estimation in this study for Turkey, both the female and male education are statistically significant. The use of consistent cross-province data from a single country, as opposed to the data problems faced in cross-country studies, may have contributed to this result. The four studies that consistently find positive and statistically significant effects of both female and the male education are by Benavot (1989), Hill and King (1993, 1995), Schultz (1995) and Boopen (2006). Our pooled estimation results are similar to these studies.

\section{Concluding Remarks}

This report examined the separate effects of female and male educational attainment as well as the effect of an educational gender gap on economic development in Turkey, using census data for the period 1975-2000. We strived to find answers to the questions of i) whether in the long run, higher levels of female and male education result in a higher level of output per worker and also ii) whether a rise in the educational gender gap adversely affects 
labor productivity across the provinces of Turkey. The pooled estimation results indicate a positive, significant effect on labor productivity of both female and male educational attainment. Opposite results are obtained for the less developed provinces and the developed provinces. While in the less developed provinces, only the male education coefficient is statistically significant, in the developed provinces only the female education is statistically significant. Thus it appears in the less developed provinces that the average schooling attainment of women is so low it fails to make an impact on development. This suggests to us not that female education is unimportant, but that average schooling attainment levels must reach some threshold before they have any impact on development/productivity. It may also be that there are fewer opportunities for the more educated workers in the less developed areas. This is clearly seen by the fact that there is significant internal migration in Turkey from the less developed areas to the developed metropolitan centers. In general, these migrants have a higher educational attainment level than the average for their home provinces. Since workers are free to migrate, they go where their education or skills may be put to more productive use. The results of this paper are robust to a number of sensitivity analyses. The sensitivity analysis included elimination of outlier observations using the Cook's distance criterion, controls for simultaneity and measurement errors with 2SLS estimation, controls for omitted variables by including regional dummy variables, steady-state versus growth equation equations and controls for different samples by considering less developed and developed provinces separately. Our OLS and 2SLS results in the sensitivity analysis indicate a positive and significant coefficient for female education and an insignificant coefficient for male education. The effect of female education appears to be stronger for the developed provinces than for the less developed provinces. Furthermore, a gender gap in education has a negative and significant effect on productivity as expected in all of the provinces as well as in the less developed and the developed provinces.

We propose two explanations for the somewhat lower female education coefficient than that of male education in the pooled estimations. First, female production tends to be concentrated in low value-added sectors that do not require high skills or education levels. One of the important features of Turkey's economy is the rapid urbanization of the population with a continual decline in the agricultural share in production. The extremely low levels of urban female labor force participation may be attributed to the decline in agricultural production combined with a lack of job opportunities in the urban sector (Tansel, 2002). Thus, gender differences in the sectoral division of labor may help explain why increases in female 
education lead to lower increases in labor productivity than do increases in male education. The second explanation is that studies have shown that returns to education rise with the education level. If we accept that returns to education are predominantly based on the productivity of individuals, then the relatively higher level of male education is expected to result in a higher contribution to productivity. However, micro studies have shown that returns to education for females are, in general, higher than that for males so that the first explanation may be more plausible.

\section{Limitations of the Study and Directions for Further Research}

A shortcoming of the model of labor productivity used in this study is that it fails to address the possibility of positive externalities of female education on labor productivity in general through its effect on the accumulation of education and health capital. Thus, female education has a dual role to play in economic development. The first is its direct effect on female productivity and the second is its indirect effect on both male and female productivity since educated mothers will pay greater attention to the education and health of their children, who will become the next generation of workers. A future direction of study would be to develop and estimate a model that incorporates this important dual aspect of female education in development.

Another important improvement may be to account for entrepreneurial capital, which is not necessarily tied to the level of formal education. In some provinces, such as Çorum, which have been dubbed as the "Anatolian Tigers" because of their economic performance, businessmen use overseas ties to "import" expertise in order to help set up or build businesses in their home provinces. In addition, the model is based on an aggregate production function that ties inputs to outputs. Such a model does not directly incorporate the effect of inefficiencies in production due to the unemployment or underemployment of resources. Our data is based on the labor force, which includes the unemployed who do not contribute anything to production. Other inefficiencies that are ignored by this model which may account for productivity differences across provinces are the possibility of education-job mismatch, which is an important characteristic of the Turkish labor market, and possible differences in the quality of education across provinces.

Investments in human capital, especially public spending on education and health, may also have an important effect on economic growth or labor productivity in many developing 
countries. Public spending in developing areas improves access to education and health services and leads to a more equal distribution of human capital across an economy, including gender equality. This is therefore an important avenue for further research. Our study has concentrated on human capital stocks rather than investments since this data is more readily available at the provincial level than data on public spending.

\section{Conclusions and Policy Implications}

Nevertheless, the results in this report support the emphasis placed by the international agencies, such as the World Bank, on the role of female education in development and growth, especially for the developing countries. Therefore, the important policy implication is that since both the female and the male education attainments contribute positively to labor productivity, the education of female workers as well as that of male workers should be given equal emphasis. Conversely, policymakers should aim to decrease educational gender gaps, which are found to adversely affect labor productivity. Policymakers could concentrate on explicitly targeting girls' education with subsidies to parents to enroll girls as well as genderneutral policy of increasing physical accessibility of schools in locations where gender gaps are large and persistent. With the words used by Hill and King (1993) and Knowles et al. (2002), our evidence indicates that educational gender gaps are "a brake on economic development."

\section{References}

Anderson, T. W. (1951) "Estimating linear restrictions on regression coefficients for multivariate normal distributions," Annals of Mathematical Statistics, 20, 46-63.

Barro, R. J. (1991) "Economic growth in a cross section of countries," Quarterly Journal of Economics, 106, 407-443.

Barro, R. J. (1994) "Sources of economic growth," Carnegie-Rochester Conference Series on Public Policy, 40, 1-46.

Barro, R. J. and Sala-i-Martin, X. (1995) Economic Growth, New York: McGraw-Hill.

Barro, R. J. (1996a) “Democracy and growth,” Journal of Economic Growth, 1, 1-27. 
Barro, R.J. (1996b) "Inflation and growth," Federal Reserve Bank of St Louis Review, May/June, 153-169.

Barro, R. J. (1997) Determinants of Economic Growth: A Cross-Country Empirical Study, Cambridge, MA: MIT Press.

Barro, R. J. (1999a) "Human capital and growth in cross-country regressions," Swedish Economic Policy Review, 6, 237-277.

Barro, R. J. (1999b) “Inequality, growth, and investment," NBER Working Paper Series No. 7038, National Bureau of Economic Research, Cambridge, MA.

Belsley, D. A., Kuh, E. and Welsch, R. E. (1980) Regression Diagnostics: Identifying Influential Data and Sources of Collinearity, New York: John Wiley and Sons Co.

Benavot, A. (1989) "Education, gender, and economic development: a cross-national study," Sociology of Education, 62, 14-32.

Bils, M. and Klenow, P. J. (1998) "Does schooling cause growth or the other way around?" NBER Working Paper Series No. 6393, National Bureau of Economic Research, Cambridge, MA.

Boopen, S. (2006) "Are there gender-separate education effects on growth? A dynamic time series analysis," Mimeo. School of Public Sector Policy and Management, University of Technology, Mauritius.

Caselli, F., Esquivel, G. and Lefort, F. (1996) "Reopening the convergence debate: A new look at cross-country growth empirics," Journal of Economic Growth, 1, 363-389.

Celasun, M. (1989) “Income distribution and employment aspects of Turkey's post-1980 adjustment," METU Studies in Development, 16(3-4), 1-31. 
Dollar, D. and Gatti, R. (1999) “Gender inequality, income, and growth: are good times good for women?” World Bank, Policy Research Report on Engendering Development, Working Paper Series, No. 1. Washington, D.C.

Durham, J. B. (1999) "Economic growth and political regimes," Journal of Economic Growth, 4, 81-111.

Engelbrecht, H. J. (1997) "Human Capital R\&D and North-South Knowledge Spillovers," Department of Applied and International Economics, Discussion Paper No. 98.03. Massey University, Albany, New Zealand.

Evans, J. (2009) "Female education as a determinant of economic growth: Delineating the impact of gender-specific education on economic growth," paper presented at the annual meeting of the ISA-ABRI joint international meeting, Pontifical Catholic University, Rio de Janeiro, Brazil, July 20-24.

Forbes, K. J. (2000) “A Reassessment of the Relationship between inequality and growth," American Economic Review, 90(4), 869-887.

Hansen, L. P. (1982) "Large sample properties of generalized method of moments estimators," Econometrica, 50, 1029-1054.

Hanushek, E. A. and Wößmann, L. (2007) "The role of education quality on economic growth,” World Bank Policy Research Working Paper No. 4122, Washington, DC.

Hill, M.A. and King, E.M. (1993) “Women's education in developing countries: an overview," in Elizabeth M. King and M. Anne Hill (eds) Women's Education in Developing Countries: Barriers, Benefits and Policies, Baltimore: Johns Hopkins University Press, 1-50.

Hill, M.A. and King, E.M. (1995) "Women's education and economic well-being," Feminist Economics 1, 21-46. 
Islam, N. (1995) “Growth empirics: A panel approach,” Quarterly Journal of Economics, 111, 1127-1170.

Jamison, E. A., Jamison, D. T. and Hanushek, E. A. (2006) "The effects of education quality on income growth and mortality decline," NBER Working Paper Series No. 12652, National Bureau of Economic Research, Cambridge, MA.

Kalaitzidakis, P., Mamuneas, T. P., Savvides A. and Stengos T. (2001) "Measures of human capital and nonlinearities in economic growth," Journal of Economic Growth, 6, 229-254.

Kara, O. (2006) “Occupational gender wage discrimination in Turkey," Journal of Economic Studies, 33(2), 130-143.

Karaarslan, E. (2005) "Kamu kesimi eğitim harcamalarının analizi," (An analysis of public sector education expenditures), Maliye Dergisi, No. 149, 36-73. (http://portal1.sgb.gov.tr/calismalar/yayinlar/md/149/erkankaraarslan.pdf)

Klasen, S. (2002) "Low schooling for girls, slower growth for all? Cross-country evidence on the effect of gender inequality in education on economic development," World Bank Economic Review, 16(3), 345-373.

Knowles, S. and Owen, P. D. (1995) "Health capital and cross-country variation in income per capita in the Mankiw-Romer-Weil model”, Economics Letters, 48, 99-106.

Knowles, S. and Owen, P.D. (1997) "Education and health in an effective-labour empirical growth model," Economic Record, 73, 314-28.

Knowles, S., Lorgelly, P. K. and Owen, P. D. (2002) “Are educational gender gaps a brake on economic development? Some cross-country empirical evidence," Oxford Economic Papers, 54, 118-149. 
Lau, L.J., Jamison, D.T., Liu, S. and Rivkin S. (1993) "Education and economic growth: Some cross-sectional evidence from Brazil," Journal of Development Economics, 41, 45-70.

Li, G. (1985) "Robust Regression," in D. C. Hoaglin, F. Mosteller and J. W. Tukey (eds) Exploring Data Tables, Trends and Shapes, New York: John Wiley and Sons Co., 281-343.

Lorgelly, P. K. and Owen, P. D. (1999) "The effect of female and male schooling on economic growth the Barro-Lee model," Empirical Economics, 24, 537-557.

Lucas, Robert E. (1988) “On the mechanics of economic development," Journal of Monetary Economics, 22, 3-42.

Mankiw, N. G., Phelps, E. S. and Romer, P. M. (1995) "The growth of nations," Brookings Papers on Economic Activity, 5th Anniversary Issue, 26(1995-1), 275-326.

Mankiw, N. G., Romer, D. and Weil, D. N. (1992) "A contribution to the empirics of economic growth," Quarterly Journal of Economics, 107, 407-437.

Moon, H. R. and Phillips, P. C. B. (1998) "A reinterpretation of the Feldstein-Horioka regressions from a nonstationary panel viewpoints," mimeo, Department of Economics, Yale University, New Haven.

Özmucur, S. (1992) Productivity and profitability: The Turkish Case, İstanbul: Boğaziçi University Publications.

Özötün, E. (1980) Illler İtibariyle Türkiye Gayri Safi Yurtiçi Hasılası - Kaynak ve Yöntemler 1975-1978 (Provincial Distribution of the Gross Domestic Product of Turkey Sources and Methods 1975-1978), Publication No. 907, Ankara: State Institute of Statistics. 
(1988) Türkiye Gayri Safi Yurtiçi Hasılasının Illler İtibariyle Dă̆ılımı,1979-1986 (Provincial Distribution of the Gross Domestic Product of Turkey 1979-1986), Publication No. 1988/8, İstanbul: İstanbul Chamber of Industry Research Department.

Pesaran, M. H. and Smith, R. (1995) "Estimating long-run relationships from dynamic heterogeneous panels," Journal of Econometrics, 68(1), 79-113.

Perotti, R. (1996) "Growth income distribution and Democracy, “ Journal of Economic Growth, 1, 149-187.

Pritchet, L. and Summers, L. H. (1996) "Wealthier is healthier," Journal of Human Resources, 31, 841-868.

Romer, P. M. (1990) “The origins of endogenous growth,” Journal of Economic Perspectives, $8,3-22$.

Rousseeuw, P. J. and Leroy, A. M. (1987) Robust Regression and Outlier Detection, New York: John Wiley and Sons Co.

Sadeghi, J. M. (1995) “The relationship of gender difference in education to economic growth: a cross-country analysis," Economic Research Forum, Working Paper No. 9521, Cairo, Egypt.

Sayg1lı, Ş., Cihan, C. and Yurtoğlu, H. (2005) Türkiye ekonomisinde sermaye birikimi, verimlilik ve büyüme: 1972-2003 (Capital accumulation, efficiency and growth in the Turkish economy: 1972-2003), Publication No. DPT:2686, Ankara: State Planning Organization.

Schultz, T. P. (1995) "Investments in schooling and health of women and men: Quantities and returns," in T. P. Schultz (ed.) Investment in Women's Human Capital, Chicago, Illinois: University of Chicago Press.

Stokey, N. (1994) "Comments on Barro and Lee," Carnegie-Rochester Conference Series on Public Policy, 40, 47-57. 
Tamer, M. (2007) "Kamu eğitim harcamalarını genç nüfusa bölersek," (If we divide educational expenditures by the size of the young population) Milliyet, 17 May 2007. (http://www.milliyet.com.tr/2007/05/17/yazar/tamer.html)

Tansel, A and Güngör, N. D. (1997) “The educational attainment of Turkey’s labor force: A comparison across provinces and over time," METU Studies in Development, 24(4), 531-547.

Taymaz, E. and Suiçmez, H. (2005) Türkiye'de verimlilik, büyüme ve kriz (Efficiency, growth and crisis in Turkey), Ankara: Milli Prodüktivite Merkezi.

Uygur, E. (1993) Financial liberalization and economic performance in Turkey, Ankara: The Central Bank of the Republic of Turkey.

Yamarik, S. and Ghosh, S. (2004) "Is female education productive? A reassessment of its effects and determinants," mimeo, Department of Economics, Tufts University, Medford, MA, USA. 
TABLE 1: Average Years of Schooling of the Labour Force by Gender, Census Year and Region

\begin{tabular}{lcccccccccccc}
\hline & \multicolumn{2}{c}{$\mathbf{1 9 7 0}$} & \multicolumn{2}{c}{$\mathbf{1 9 7 5}$} & \multicolumn{2}{c}{$\mathbf{1 9 8 0}$} & \multicolumn{2}{c}{$\mathbf{1 9 8 5}$} & \multicolumn{2}{c}{$\mathbf{1 9 9 0}$} & \multicolumn{2}{c}{$\mathbf{2 0 0 0}$} \\
Regions & male & female & male & female & male & female & male & female & male & female & male & female \\
\hline & & & & & & & & & & & \\
Marmara & 4.41 & 2.78 & 4.94 & 3.61 & 5.64 & 4.40 & 6.07 & 5.08 & 6.48 & 5.76 & 7.53 & 7.16 \\
Aegean & 3.73 & 1.94 & 4.28 & 2.69 & 5.08 & 3.27 & 5.54 & 3.99 & 5.93 & 4.47 & 6.97 & 5.57 \\
Mediterranean & 3.53 & 1.50 & 4.14 & 2.30 & 4.99 & 2.85 & 5.46 & 3.67 & 5.89 & 4.21 & 7.07 & 5.43 \\
Black Sea & 3.05 & 0.94 & 3.72 & 1.69 & 4.62 & 2.26 & 5.17 & 3.10 & 5.61 & 3.49 & 6.75 & 4.39 \\
Central Anatolia & 3.97 & 1.75 & 4.59 & 2.57 & 5.45 & 3.22 & 5.92 & 3.98 & 6.36 & 4.59 & 7.62 & 5.92 \\
Southeast Anatolia & 2.15 & 0.38 & 2.78 & 0.66 & 3.65 & 0.83 & 4.31 & 1.38 & 4.75 & 1.81 & 6.07 & 2.80 \\
Eastern Anatolia & 2.88 & 0.84 & 3.34 & 1.26 & 4.19 & 1.39 & 4.79 & 2.15 & 5.24 & 2.55 & 6.64 & 3.27 \\
& & & & & & & & & & & & \\
Turkey & 3.62 & 1.55 & 4.18 & 2.24 & 5.02 & 2.77 & 5.52 & 3.51 & 5.95 & 4.07 & 7.13 & 5.36 \\
& & & & & & & & & & &
\end{tabular}

Source: Tansel and Güngör (1997) for 1970-1990; 2000 data calculated from the provincial census booklets.

TABLE 2:

Gender Ratio - Female Schooling Attainment as a Percentage of Male Schooling Attainment

\begin{tabular}{lcccccc}
\hline \hline Regions & $\mathbf{1 9 7 0}$ & $\mathbf{1 9 7 5}$ & $\mathbf{1 9 8 0}$ & $\mathbf{1 9 8 5}$ & $\mathbf{1 9 9 0}$ & $\mathbf{2 0 0 0}$ \\
\hline & & & & & & \\
Marmara & 0.63 & 0.73 & 0.78 & 0.84 & 0.89 & 0.95 \\
Aegean & 0.52 & 0.63 & 0.64 & 0.72 & 0.75 & 0.80 \\
Mediterranean & 0.42 & 0.56 & 0.57 & 0.67 & 0.71 & 0.77 \\
Black Sea & 0.31 & 0.45 & 0.49 & 0.60 & 0.62 & 0.65 \\
Central Anatolia & 0.44 & 0.56 & 0.59 & 0.67 & 0.72 & 0.78 \\
Southeast Anatolia & 0.18 & 0.24 & 0.23 & 0.32 & 0.38 & 0.46 \\
Eastern Anatolia & 0.29 & 0.38 & 0.33 & 0.45 & 0.49 & 0.49 \\
& & & & & & \\
TURKEY & 0.43 & 0.54 & 0.55 & 0.64 & 0.68 & 0.75 \\
\hline \hline
\end{tabular}

Source: Tansel and Güngör (1997) for 1970-1990; 2000 data calculated from the provincial census booklets 
FIGURE 1

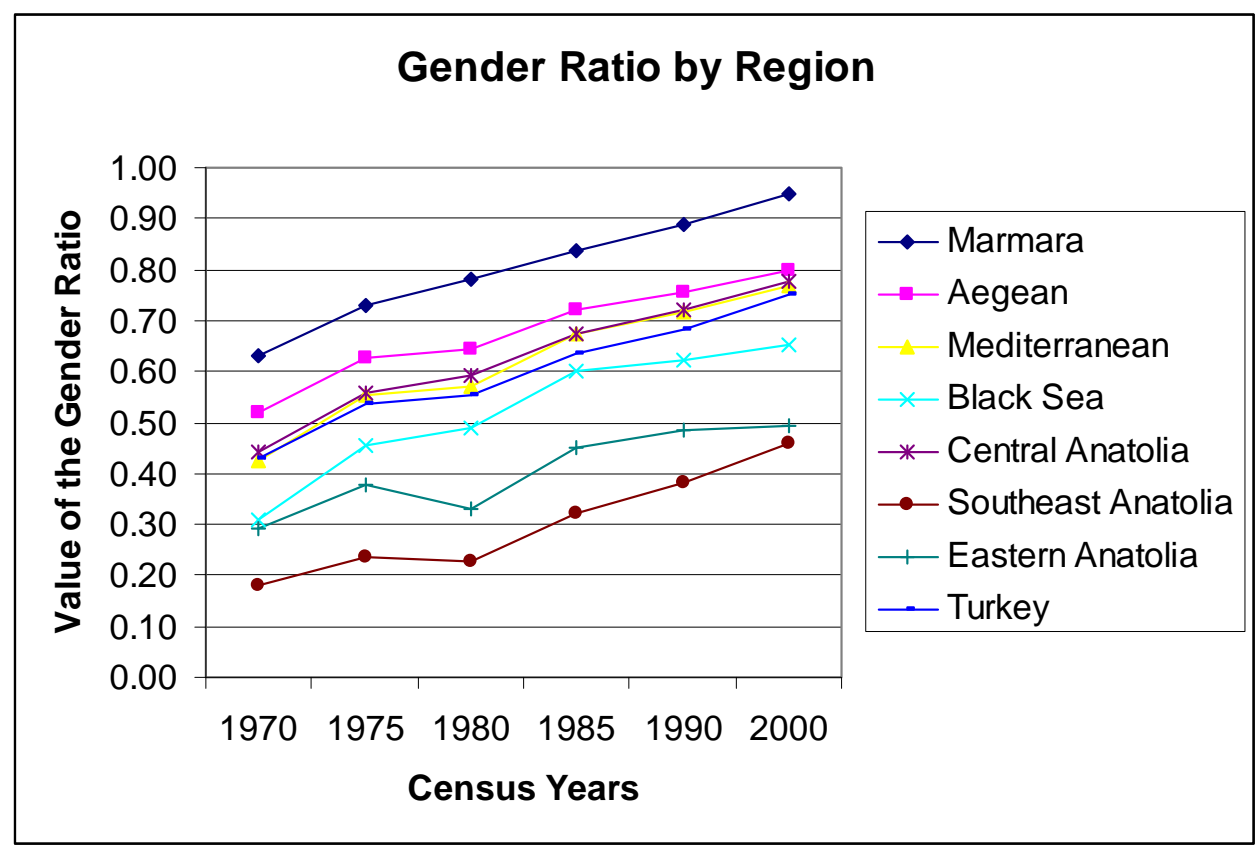

TABLE 3: Mean Years of Schooling as ratio of the Mean Years of the Schooling of the Marmara Region

\begin{tabular}{|c|c|c|c|c|c|c|c|c|c|c|c|c|}
\hline \multirow[b]{2}{*}{ Regions } & \multicolumn{2}{|c|}{1970} & \multicolumn{2}{|c|}{1975} & \multicolumn{2}{|c|}{1980} & \multicolumn{2}{|c|}{1985} & \multicolumn{2}{|c|}{1990} & \multicolumn{2}{|c|}{2000} \\
\hline & male & female & male & female & male & female & male & female & male & female & male & female \\
\hline Marmara & 1.00 & 1.00 & 1.00 & 1.00 & 1.00 & 1.00 & 1.00 & 1.00 & 1.00 & 1.00 & 1.00 & 1.00 \\
\hline Aegean & 0.84 & 0.70 & 0.87 & 0.75 & 0.90 & 0.74 & 0.91 & 0.79 & 0.92 & 0.78 & 0.93 & 0.78 \\
\hline Mediterranean & 0.80 & 0.54 & 0.84 & 0.64 & 0.88 & 0.65 & 0.90 & 0.72 & 0.91 & 0.73 & 0.94 & 0.76 \\
\hline Black Sea & 0.69 & 0.34 & 0.75 & 0.47 & 0.82 & 0.51 & 0.85 & 0.61 & 0.87 & 0.61 & 0.90 & 0.61 \\
\hline $\begin{array}{l}\text { Central Anatolia } \\
\text { Southeast }\end{array}$ & 0.90 & 0.63 & 0.93 & 0.71 & 0.97 & 0.73 & 0.98 & 0.78 & 0.98 & 0.80 & 1.01 & 0.83 \\
\hline Anatolia & 0.49 & 0.14 & 0.56 & 0.18 & 0.65 & 0.19 & 0.71 & 0.27 & 0.73 & 0.31 & 0.81 & 0.39 \\
\hline Eastern Anatolia & 0.65 & 0.30 & 0.68 & 0.35 & 0.74 & 0.32 & 0.79 & 0.42 & 0.81 & 0.44 & 0.88 & 0.46 \\
\hline Turkey & 0.82 & 0.56 & 0.85 & 0.62 & 0.89 & 0.63 & 0.91 & 0.69 & 0.92 & 0.71 & 0.95 & 0.75 \\
\hline
\end{tabular}

Source: calculated from Tansel and Güngör (1997) for 1970-1990; 2000 data calculated from the provincial census booklets. 
TABLE 4: Average Years of Schooling of the Labour Force

\begin{tabular}{cccc}
\hline & \multicolumn{3}{c}{ Full (67 provinces) } \\
\cline { 2 - 4 } $\mathbf{1 9 7 5}$ & $\mathbf{T}$ & $\mathbf{M}$ & $\mathbf{F}$ \\
\cline { 2 - 4 } $\mathbf{1 9 8 0}$ & 3.09 & 3.78 & 1.99 \\
$\mathbf{1 9 8 5}$ & 3.76 & 4.63 & 2.48 \\
$\mathbf{1 9 9 0}$ & 4.39 & 5.18 & 3.22 \\
$\mathbf{2 0 0 0}$ & 4.84 & 5.62 & 3.66 \\
& 5.96 & 6.82 & 4.58 \\
& Less Developed (38 provinces) \\
\cline { 2 - 4 } $\mathbf{1 9 7 5}$ & $\mathbf{T}$ & $\mathbf{M}$ & $\mathbf{F}$ \\
$\mathbf{n y 8 0}$ & 3.57 & 3.37 & 1.40 \\
$\mathbf{1 9 8 5}$ & 3.19 & 4.25 & 1.77 \\
$\mathbf{1 9 9 0}$ & 4.86 & 4.85 & 2.51 \\
$\mathbf{2 0 0 0}$ & 5.49 & 5.32 & 2.91 \\
& More Developed (29 provinces) \\
& $\mathbf{T}$ & $\mathbf{M}$ & $\mathbf{F}$ \\
$\mathbf{1 9 7 5}$ & 3.77 & 4.31 & 2.77 \\
$\mathbf{1 9 8 0}$ & 4.51 & 5.13 & 3.42 \\
$\mathbf{1 9 8 5}$ & 5.08 & 5.60 & 4.14 \\
$\mathbf{1 9 9 0}$ & 5.52 & 6.02 & 4.64 \\
$\mathbf{2 0 0 0}$ & 6.57 & 7.10 & 5.67 \\
\hline \hline
\end{tabular}

Source: calculated from Tansel and Güngör (1997) for 1970-1990; 2000

data calculated from the provincial census booklets 
TABLE 5: Pooled Robust Regression (rreg) Estimates of the Steady-State Equation for GDP per Worker 1975-2000 Dependent Variable: Average log of GDP per Worker

\begin{tabular}{|c|c|c|c|c|c|c|c|c|c|}
\hline \multirow{2}{*}{$\frac{\text { VARIABLES }}{\ln \left(s_{k}\right)}$} & \multicolumn{3}{|c|}{ All Provinces } & \multicolumn{3}{|c|}{ Less Developed Provinces } & \multicolumn{3}{|c|}{ Developed Provinces } \\
\hline & $0.180 * * *$ & $0.117 * *$ & $0.168 * * *$ & 0.116 & 0.0984 & $0.121^{*}$ & -0.114 & -0.141 & -0.113 \\
\hline & $(0.0632)$ & $(0.0591)$ & $(0.0612)$ & $(0.0796)$ & $(0.0692)$ & $(0.0696)$ & $(0.108)$ & $(0.113)$ & $(0.132)$ \\
\hline \multirow[t]{2}{*}{$\ln (\mathrm{n}+\mathrm{g}+\delta)$} & $0.144 * * *$ & $0.0967 * * *$ & $0.0939 * * *$ & $0.115 * * *$ & $0.0536 * * *$ & $0.0593 * * *$ & $0.145^{* * *}$ & $0.136 * * *$ & $0.131 * * *$ \\
\hline & $(0.0118)$ & $(0.0124)$ & $(0.0122)$ & $(0.0144)$ & $(0.0152)$ & $(0.0148)$ & $(0.0207)$ & $(0.0212)$ & $(0.0209)$ \\
\hline \multirow[t]{2}{*}{$\ln (e f)^{*}$} & $0.280 * * *$ & $0.165^{*}$ & $0.178 *$ & 0.0738 & -0.0524 & -0.0741 & $0.996^{* * *}$ & $1.038 * * *$ & $0.920 * * *$ \\
\hline & $(0.0680)$ & $(0.0893)$ & $(0.0954)$ & $(0.0851)$ & $(0.106)$ & $(0.111)$ & $(0.143)$ & $(0.179)$ & $(0.178)$ \\
\hline \multirow[t]{2}{*}{$\ln (e m)^{*}$} & $0.371 * *$ & $0.686^{* * *}$ & $0.702 * *$ & $0.439 *$ & $0.824 * * *$ & $1.040 * * *$ & -0.418 & -0.395 & 0.332 \\
\hline & $(0.182)$ & $(0.199)$ & $(0.293)$ & $(0.230)$ & $(0.240)$ & $(0.347)$ & $(0.298)$ & $(0.350)$ & $(0.529)$ \\
\hline \multirow[t]{2}{*}{$\ln (x)^{*}$} & $0.108 * * *$ & $0.188 * * *$ & $0.170 * * *$ & $0.190 * * *$ & $0.318 * * *$ & $0.274 * * *$ & -0.0566 & -0.0284 & -0.0878 \\
\hline & $(0.0397)$ & $(0.0367)$ & $(0.0391)$ & $(0.0518)$ & $(0.0490)$ & $(0.0500)$ & $(0.0494)$ & $(0.0525)$ & $(0.0591)$ \\
\hline \multirow[t]{2}{*}{ aegean } & & $-0.0967 *$ & $-0.0956^{*}$ & & 0 & 0 & & 0.0321 & 0.0416 \\
\hline & & $(0.0561)$ & $(0.0553)$ & & (0) & (0) & & $(0.0484)$ & $(0.0496)$ \\
\hline \multirow[t]{2}{*}{ medit } & & $-0.141 * *$ & $-0.146^{* *}$ & & -0.108 & -0.144 & & 0.000734 & -0.0158 \\
\hline & & $(0.0593)$ & $(0.0581)$ & & $(0.172)$ & $(0.167)$ & & $(0.0564)$ & $(0.0545)$ \\
\hline \multirow[t]{2}{*}{ blacksea } & & $-0.328 * * *$ & $-0.319 * * *$ & & $-0.500 * * *$ & $-0.494 * * *$ & & -0.0385 & -0.0133 \\
\hline & & $(0.0561)$ & $(0.0554)$ & & $(0.127)$ & $(0.124)$ & & $(0.103)$ & $(0.103)$ \\
\hline \multirow[t]{2}{*}{ central } & & $-0.222 * * *$ & $-0.223 * * *$ & & $-0.363 * * *$ & $-0.369 * * *$ & & -0.0804 & $-0.128 * *$ \\
\hline & & $(0.0546)$ & $(0.0537)$ & & $(0.129)$ & $(0.125)$ & & $(0.0630)$ & $(0.0647)$ \\
\hline \multirow[t]{2}{*}{ southeast } & & -0.0140 & -0.00812 & & $-0.258 *$ & $-0.257^{*}$ & & $0.291 * *$ & $0.323 * * *$ \\
\hline & & $(0.0868)$ & $(0.0866)$ & & $(0.155)$ & $(0.150)$ & & $(0.115)$ & $(0.116)$ \\
\hline \multirow[t]{2}{*}{ east } & & $-0.373 * * *$ & $-0.367 * * *$ & & $-0.636 * * *$ & $-0.629 * * *$ & & 0 & 0 \\
\hline & & $(0.0754)$ & $(0.0746)$ & & $(0.141)$ & $(0.137)$ & & (0) & (0) \\
\hline time 8085 & & & $-0.140 * * *$ & & & $-0.196 * * *$ & & & $-0.189 * * *$ \\
\hline & & & (0.0499) & & & $(0.0667)$ & & & $(0.0676)$ \\
\hline time 8590 & & & $-0.101^{*}$ & & & $-0.160^{*}$ & & & $-0.183 * *$ \\
\hline & & & $(0.0605)$ & & & $(0.0813)$ & & & $(0.0875)$ \\
\hline time 9000 & & & -0.00669 & & & -0.100 & & & -0.199 \\
\hline & & & $(0.0825)$ & & & $(0.110)$ & & & $(0.134)$ \\
\hline Constant & $-0.796^{*}$ & -0.117 & -0.0444 & -0.101 & $1.304 * *$ & 0.804 & $-2.217 * * *$ & $-2.103 * * *$ & $-3.276^{* * *}$ \\
\hline & $(0.437)$ & $(0.407)$ & $(0.576)$ & $(0.571)$ & $(0.547)$ & $(0.692)$ & $(0.571)$ & $(0.580)$ & $(1.096)$ \\
\hline Observations & 268 & 268 & 268 & 152 & 152 & 152 & 116 & 116 & 116 \\
\hline R-squared & 0.797 & 0.836 & 0.842 & 0.667 & 0.747 & 0.766 & 0.789 & 0.794 & 0.813 \\
\hline adj.Rsq & 0.794 & 0.829 & 0.834 & 0.656 & 0.729 & 0.744 & 0.779 & 0.774 & 0.789 \\
\hline F test & 206.3 & 118.3 & 96.48 & 58.49 & 41.59 & 34.81 & 82.21 & 40.36 & 34.04 \\
\hline p-value & 0 & 0 & 0 & 0 & 0 & 0 & 0 & 0 & 0 \\
\hline test of restriction & 0.28 & 0.10 & 1.27 & 0.00 & 0.37 & 0.69 & 4.67 & 4.90 & 2.88 \\
\hline p-value of restriction & 0.599 & 0.747 & 0.262 & 0.991 & 0.546 & 0.407 & 0.0329 & 0.0290 & 0.0929 \\
\hline Pooled Robust Regre & ession (rreg) & Estimates & for the Gent & $r$ Gap Par & metrization & & & & \\
\hline Gender Gap and & & & & & & & & & \\
\hline Female Education & & & & & & & & & \\
\hline $\ln (e f)^{*}$ & $0.651 * * *$ & $0.851 * * *$ & $0.879 * * *$ & $0.513 * * *$ & $0.772 * * *$ & $0.966 * * *$ & $0.578 * * *$ & $0.643 * * *$ & $1.252 * * *$ \\
\hline & $(0.134)$ & $(0.132)$ & $(0.224)$ & $(0.169)$ & $(0.159)$ & $(0.266)$ & $(0.193)$ & $(0.211)$ & $(0.416)$ \\
\hline $\ln (e m)^{*}-\ln (e f)^{*}$ & $0.371 * *$ & $0.686^{* * *}$ & $0.702 * *$ & $0.439 *$ & $0.824 * * *$ & $1.040 * * *$ & -0.418 & -0.395 & 0.332 \\
\hline & $(0.182)$ & $(0.199)$ & $(0.293)$ & $(0.230)$ & $(0.240)$ & $(0.347)$ & $(0.298)$ & $(0.350)$ & $(0.529)$ \\
\hline Gender Gap and & & & & & & & & & \\
\hline Male Education & & & & & & & & & \\
\hline $\ln (\mathrm{em})^{*}$ & $0.651 * * *$ & $0.851 * * *$ & $0.879 * * *$ & $0.513^{* * *}$ & $0.772 * * *$ & $0.966^{* * *}$ & $0.578 * * *$ & $0.643 * * *$ & $1.252 * * *$ \\
\hline & $(0.134)$ & $(0.132)$ & $(0.224)$ & $(0.169)$ & $(0.159)$ & $(0.266)$ & $(0.193)$ & $(0.211)$ & $(0.416)$ \\
\hline $\ln (e m)^{*}-\ln (e f)^{*}$ & $-0.280 * * *$ & $-0.165^{*}$ & $-0.178^{*}$ & -0.0738 & 0.0524 & 0.0741 & $-0.996 * * *$ & $-1.038 * * *$ & $-0.920 * * *$ \\
\hline & $(0.0680)$ & $(0.0893)$ & $(0.0954)$ & $(0.0851)$ & $(0.106)$ & $(0.111)$ & $(0.143)$ & $(0.179)$ & $(0.178)$ \\
\hline Implied Elasticities $f$ & rom the Res & stricted Mod & del Estimat & & & & & & \\
\hline$\alpha$ & $0.14 * * *$ & $0.09 * * *$ & $0.09 * * *$ & $0.10 * * *$ & $0.05 * * *$ & $0.05 * * *$ & & & $0.12 * * *$ \\
\hline & 0.01 & 0.01 & 0.01 & 0.01 & 0.01 & 0.01 & & & 0.02 \\
\hline$\beta_{f}$ & $0.27 * * *$ & $0.16^{* *}$ & 0.13 & 0.04 & -0.09 & -0.12 & & & $0.82 * * *$ \\
\hline & 0.06 & 0.08 & 0.09 & 0.08 & 0.10 & 0.10 & & & 0.16 \\
\hline$\beta_{m}$ & 0.13 & $0.52 * * *$ & $0.76 * * *$ & 0.33 & $0.78 * * *$ & $1.06 * * *$ & & & 0.30 \\
\hline & 0.16 & 0.18 & 0.27 & 0.21 & 0.23 & 0.33 & & & 0.46 \\
\hline$\psi$ & $0.08 * *$ & $0.17 * * *$ & $0.13 * * *$ & $0.16 * * *$ & $0.31 * * *$ & $0.26 * * *$ & & & -0.08 \\
\hline & 0.04 & 0.03 & 0.04 & 0.05 & 0.05 & 0.05 & & & 0.05 \\
\hline
\end{tabular}

Standard errors in parentheses; * significant at $10 \% ;{ }^{* *}$ significant at $5 \% ; * * *$ significant at $1 \%$ 
TABLE 6: Summary Statistics for the Dependent and Explanatory Variables

\begin{tabular}{|c|c|c|c|c|c|}
\hline Variable & $\begin{array}{c}\text { Number of } \\
\text { Observations }\end{array}$ & Mean & $\begin{array}{l}\text { Standard } \\
\text { Deviation } \\
\end{array}$ & Min & Max \\
\hline \multicolumn{6}{|l|}{ All Provinces } \\
\hline $\ln (Y / L)^{*}$ & 268 & 0.53 & 0.56 & -0.72 & 2.31 \\
\hline $\ln \left(s_{k}\right)$ & 268 & 11.32 & 1.97 & 2.06 & 15.46 \\
\hline $\ln (\mathrm{n}+\mathrm{g}+\delta)$ & 268 & -2.75 & 0.28 & -4.33 & -1.86 \\
\hline $\ln (e f)^{*}$ & 268 & 1.01 & 0.57 & -1.40 & 2.12 \\
\hline $\ln (\mathrm{em})^{*}$ & 268 & 1.62 & 0.20 & 0.89 & 2.08 \\
\hline $\ln (x)^{*}$ & 268 & -6.54 & 0.53 & -7.94 & -5.19 \\
\hline $\ln (e m)^{*}-\ln (e f)^{*}$ & 268 & 0.61 & 0.40 & -0.15 & 2.29 \\
\hline \multicolumn{6}{|c|}{ Less Developed Provinces } \\
\hline $\ln (Y / L)^{*}$ & 152 & 0.23 & 0.44 & -0.72 & 1.26 \\
\hline $\ln \left(s_{k}\right)$ & 152 & 10.37 & 1.94 & 2.06 & 14.14 \\
\hline $\ln (\mathrm{n}+\mathrm{g}+\delta)$ & 152 & -2.82 & 0.31 & -4.33 & -1.86 \\
\hline $\ln (e f)^{*}$ & 152 & 0.74 & 0.59 & -1.40 & 1.52 \\
\hline $\ln (\mathrm{em})^{*}$ & 152 & 1.55 & 0.21 & 0.89 & 1.92 \\
\hline $\ln (x)^{*}$ & 152 & -6.72 & 0.55 & -7.94 & -5.25 \\
\hline $\ln (e m)^{*}-\ln (e f)^{*}$ & 152 & 0.81 & 0.41 & 0.28 & 2.29 \\
\hline \multicolumn{6}{|l|}{ Developed Provinces } \\
\hline $\ln (Y / L)^{*}$ & 116 & 0.93 & 0.44 & 0.19 & 2.31 \\
\hline $\ln \left(s_{k}\right)$ & 116 & 12.57 & 1.16 & 9.57 & 15.46 \\
\hline $\ln (\mathrm{n}+\mathrm{g}+\delta)$ & 116 & -2.65 & 0.19 & -3.28 & -2.22 \\
\hline $\ln (e f)^{*}$ & 116 & 1.36 & 0.30 & 0.38 & 2.12 \\
\hline $\ln (e m)^{*}$ & 116 & 1.71 & 0.15 & 1.38 & 2.08 \\
\hline $\ln (x)^{*}$ & 116 & -6.30 & 0.40 & -6.99 & -5.19 \\
\hline $\ln (e m)^{*}-\ln (e f)^{*}$ & 116 & 0.35 & 0.18 & -0.15 & 0.99 \\
\hline
\end{tabular}

